\title{
ESTIMATING FORAGE INTAKE OF LACTATING DUAL-PURPOSE COWS USING CHROMIUM OXIDE AND N-ALKANES AS EXTERNAL MARKERS
}

\author{
Dimas Estrasulas de Oliveira ${ }^{1 *}$; Sérgio Raposo de Medeiros²; Luis Orlindo Tedeschi ${ }^{3}$, Luís \\ Januário Magalhães Aroeira ${ }^{4}$; Sila Carneiro da Silva ${ }^{5}$ \\ ${ }^{1}$ UDESC - Centro Educacional do Oeste, R. Benjamin Constant, 164-D - Centro - 89801-070 - Chapecó, SC - \\ Brasil. \\ ${ }_{3}^{2}$ Embrapa Gado de Corte, BR 262 km 4, C.P. 154 - 79002-970 - Campo Grande, MS - Brasil \\ ${ }^{3}$ Texas A\&M University, 230 Kleberg Center, 2471 - TAMU, College Station, TX 77843-2471, USA. \\ ${ }_{5}^{4}$ Embrapa Gado de Leite, R. Eugênio do Nascimento, 610 - 36038-330 - Juiz de Fora, MG - Brasil. \\ USP/ESALQ - Depto. de Zootecnia, C.P. 09 - 13418-900 - Piracicaba, SP - Brasil. \\ *Corresponding author <deolivei2@terra.com.br>
}

\begin{abstract}
The n-alkanes have been used to estimate forage dry matter intake, digestibility and the diet composition in grazing animals. The objective this study was to compare chromium oxide and nalkanes techniques used to estimate forage intake. Twenty lactating dual-purpose cows receiving two sources of fat (treatments: conjugated linoleic acid (CLA) or Megalac (control)) plus $4 \mathrm{~kg}$ of concentrate were dosed with n-alkanes and chromium oxide to estimate the intake of stargrass (Cynodon nlemfüensis Vanderyst var. nlemfüensis). The in vitro dry matter (DM) digestibility of the stargrass and concentrate were used to estimate the nutritive value of the digesta. The n-alkanes between $\mathrm{C}_{23}$ and $\mathrm{C}_{36}$ were quantified in the digesta and feces. The regression between metabolizable energy requirement $(\mathrm{MEr}$, $\mathrm{Mcal} \mathrm{d}^{-1}$ ) and supply derived from forage DM intake estimated using chromium oxide was ME Intake ${ }_{\mathrm{Cr}}$ $=19.1+0.62 \mathrm{MEr}\left(\mathrm{R}^{2}=0.27\right)$ and the same relationship estimated using $\mathrm{C}_{35}: \mathrm{C}_{36} \mathrm{n}$-alkane ratio was $\mathrm{ME}$ Intake $_{\mathrm{C} 35 \mathrm{C} 36}=9.3+0.77 \mathrm{MEr}\left(\mathrm{R}^{2}=0.52\right)$. There was a treatment effect on fecal concentration of chromium oxide with daily and period variations. For the n-alkane technique, treatment and period effects and a linear effect of day of collection on the fecal concentrations of $\mathrm{C}_{35}$ were found. For $\mathrm{C}_{36}$ fecal concentrations, there was a treatment effect and a quadratic effect of collection day. There was no treatment effect on the fecal concentration of the $\mathrm{C}_{35}: \mathrm{C}_{36}$ ratio, but a period effect and a linear effect of day of collection were found. Estimates of daily intake using the two markers were different, but those obtained using the $\mathrm{C}_{35}: \mathrm{C}_{36}$ pair of n-alkanes were more precise than those obtained using chromium oxide and in vitro digestibility. Management of experimental animals could have influenced the concentration of markers in the feces, determining variations and inconsistencies that partially explain the inaccuracy of the estimates.
\end{abstract}

Key words: diet composition, digestibility, grazing

\section{ESTIMATIVA DO CONSUMO DE FORRAGEMEM VACAS MESTIÇAS LACTANTES USANDO ÓXIDO CRÔMICO E N-ALCANOS COMO MARCADORES EXTERNOS}

RESUMO: Os n-alcanos têm sido utilizados para estimar o consumo de matéria seca, a digestibilidade e a composição da dieta de animais em pastejo. O objetivo desse estudo foi comparar as técnicas de óxido crômico e n-alcanos usadas para estimar o consumo de forragem. Vinte vacas lactantes cruzas Holandês $\times$ Gir recebendo duas fontes de gordura (tratamentos: CLA (ácido linoleico conjugado) ou Megalac (controle)) mais $4 \mathrm{~kg}$ de concentrado foram dosadas com n-alcanos e óxido crômico para estimar o consumo de estrela-africana (Cynodon nlemfüensis Vanderyst var. nlemfüensis). A digestibilidade in vitro da matéria seca da estrela africana e do concentrado foi usada para estimar o valor nutritivo da dieta. Foram quantificados n-alcanos entre $\mathrm{C}_{23}$ e $\mathrm{C}_{36}$ na dieta e fezes. A regressão entre exigência e o consumo de energia metabolizável $\left(\mathrm{EMr}, \mathrm{Mcal}^{\mathrm{d}} \mathrm{d}^{-1}\right)$ derivada da matéria seca da forragem calculada usando óxido de cromo foi ConsumoCr $=19,1+0,62 \mathrm{EMr}\left(\mathrm{R}^{2}=0,27\right)$ e a mesma relação estimada usando a relação $\mathrm{C}_{35}: \mathrm{C}_{36}$ de n-alcanos foi Consumo $\mathrm{C}_{35}: \mathrm{C}_{36}=9,3+0,77 \mathrm{EMr}\left(\mathrm{R}^{2}=0,52\right)$. Houve efeito de tratamento na concentração fecal de óxido de cromo com variação diária e entre turnos. Para técnica de n-alcanos, houve efeito de tratamento e período e efeito linear de dia de coleta 
nas concentrações fecais do $\mathrm{C}_{35}$. Para as concentrações fecais do $\mathrm{C}_{36}$, houve efeito de tratamento e um efeito quadrático de dia de coleta. Não houve efeito de tratamento na concentração fecal da relação $\mathrm{C}_{35}: \mathrm{C}_{36}$, mas houve efeito de turno e efeito linear de dia de coleta. As estimativas do consumo de forragem obtidas com os dois marcadores foram diferentes, mas aquela obtida com o par de alcanos $\mathrm{C}_{35}: \mathrm{C}_{36}$ foi mais precisa que aquela obtida com o óxido crômico e a digestibilidade in vitro. $\mathrm{O}$ manejo dos animais experimentais pode ter influenciado a concentração dos marcadores nas fezes, determinando variações e inconsistências que explicam parcialmente a falta de acurácia das estimativas. Palavras-chave: composição da dieta, digestibilidade, pastejo

\section{INTRODUCTION}

Pasture is the main source of nutrients for grazing animals. They modify their diet by selecting different species and/or parts of plants, and this confers complexity to the determination of the diet composition, intake, and digestibility under grazing conditions. The most common methodology for estimating forage intake by grazing ruminants is the calculation of fecal output and forage dry matter (DM) digestibility. Fecal output is usually estimated by chromium oxide as an external marker and forage DM digestibility is measured using in vitro methods (Schneider \& Flatt, 1975; Le Du \& Penning, 1982; Mayes \& Dove, 2000). The main constraints of this methodology are the assumption that chromium oxide is completely recovered in the feces and the use of a single forage DM digestibility value for all animals. An alternative methodology has been proposed to overcome these limitations. Currently, the aliphatic saturated hydrocarbons (n-alkanes) in the cuticular wax of plants have been extensively used to estimate forage DM intake (Mayes et al., 1986; Dove \& Mayes, 1991; Genro et al., 2000) and digestibility (Mayes \& Lamb, 1984; Oliveira et al., 2000). Additionally, this technique allows the study of the botanical and/or morphological composition of plants available in a pasture or ingested by the grazing animals (Dove, 1992; Dove \& Moore, 1995; Oliveira et al., 2003).

The objective of the present research was to compare chromium oxide and n-alkane techniques for estimating forage DM intake and digestibility in lactating dual-purpose cows supplemented with or without conjugated linoleic acid (CLA) and grazing a tropical grass pasture.

\section{MATERIAL AND METHODS}

As part of a project evaluating the effects of CLA in lactating cows, an experiment was carried out

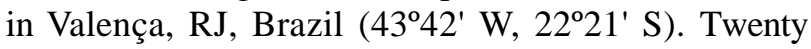
crossbred Holstein x Gir lactating cows were used, and based on previous milk yield, parity, body condition score (BCS), and body weight (BW) assigned to the treatments. Humane animal care and handling proce- dures were followed. Treatments comprised daily dosing of animals grazing a Cynodon nlemfüensis Vanderyst var. nlemfüensis pasture with $150 \mathrm{~g}$ of Megalac (Dwight \& Church, salts of calcium of palm oil) (control) or $150 \mathrm{~g}$ of CLA-60 (Dwight \& Church, salts of calcium of a mixture of isomers of CLA). Each cow received, individually, $2.0 \mathrm{~kg}$ (as-fed basis) of concentrate after the morning and afternoon milking for a total of $4.0 \mathrm{~kg} \mathrm{day}^{-1}$. The pasture was divided into fourteen 0.5 -ha paddocks and rotationally grazed according to a 28 -day grazing cycle (14 paddocks and 2-day grazing duration per paddock). Concentrate composition (DM basis) was: ground corn, 58.5\%; fish meal, 25\%; soybean meal, 5.5\%; wheat bran, $5.5 \%$; and a vitamin-mineral mix, 5.5\%.

Fat supplements (CLA or Megalac) were mixed into the concentrate used for the first meal, using the second meal in the afternoon to offer any refusal from the morning period as a means of assuring total consumption, although most of the time this was not necessary. Rations were formulated with the Cornell Net Carbohydrate and Protein System (CNCPS; Fox et al., 2004) and forage composition was assumed to be (DM basis) 35\% DM, 75\% neutral detergent fiber (NDF), 9.7\% lignin, $15 \%$ crude protein (CP), $30 \% \mathrm{~N}$ bound to the NDF as a fraction of total N (N-NDF), $8 \% \mathrm{~N}$ bound to the acid detergent fiber (ADF) as a fraction of total $\mathrm{N}(\mathrm{N}-\mathrm{ADF}), 1.6 \%$ ether extract, and $8 \%$ ash (Tedeschi et al., 2002).

Forage samples were hand-plucked (Prates, 1974) in the morning and afternoon during the two days of grazing per paddock. Three animals were followed for 30 minutes during the forage sampling procedure in an attempt to cover the entire area of the paddock and to mimic the pattern of intake and forage selection of the animals. Morphological separation of leaf lamina (leaf), leaf sheath and stem (stem), and senescent or dead material (dead) was carried out in three subsamples. The pre- and post-grazing herbage mass were measured by clipping herbage $10 \mathrm{~cm}$ above ground level at ten randomly selected areas $\left(0.25 \mathrm{~m}^{2}\right)$ per paddock in three paddocks. Forage sampling, 12 hand-plucked samples and 60 for pre and post-grazing herbage mass, were carried out in the paddocks animals in which were grazing when fecal collections were carried out. 
The hand-plucked forage samples, leaf and stem components, and concentrate were analyzed for DM, ash and CP according to AOAC (1997). The DM and ash of the fecal samples were also analyzed. Forage samples were also analyzed for NDF, ADF, NDF$\mathrm{N}$, ADF-N, and lignin according to Van Soest et al. (1991). Due to the fact that the detergent system produces unrealistic values of fiber for fish meal, the fractions of NDF, ADF, N-NDF, N-ADF, and lignin of the concentrate were estimated based on individual composition of each ingredient and their corresponding proportion of inclusion in the concentrate mix. The chemical composition of the feeds is shown in Table 1. Characterization of the ration, animal, and environment were used in the CNCPS to estimate the biological values of the used feeds. Other information, as the characterization of each animal for live weight (means, $\mathrm{CLA}=485, \mathrm{CV}=7.7 \%$; $\mathrm{MEG}=463, \mathrm{CV}=10.9 \%$ ), age (84 months), milk production (means, CLA $=15.4 \mathrm{~kg}$, $\mathrm{CV}=17.9 \%$; $\mathrm{MEG}=14.5 \mathrm{~kg}, \mathrm{CV}=17.7 \%)$ and composition $(\mathrm{CLA}$, protein $=3.1 \%, \mathrm{CV}=9.2 \%$, fat $=2.8 \%$, $\mathrm{CV}=19.2 \%$; MEG, protein $=2.9 \%, \mathrm{CV}=8.2 \%$, fat $=$ $3.3 \%, \mathrm{CV}=11.6 \%$ ), days in milk (56 days) and body condition score $(\mathrm{CLA}=3.8, \mathrm{CV}=20.0 \% ; \mathrm{MEG}=3.6$, $\mathrm{CV}=15.7 \%$ ), plus the data of the environmental conditions (previous temperature $=23.5^{\circ} \mathrm{C}$, current temperature $=24.5^{\circ} \mathrm{C}$; humidity $=75 \%$; wind speed $=4.2$ $\mathrm{km} / \mathrm{h}$; coat condition= some mud on lower body), were also entered to estimate the metabolizable energy requirements (Mcal/day, means, $\mathrm{CLA}=30.1, \mathrm{CV}=9.6 \%$; $\mathrm{MEG}=29.1, \mathrm{CV}=8.5 \%$ ), rations and animal performance. The metabolizable energy of the feeds estimated by the CNCPS was used.

Cows were milked at 05:00 a.m. After milking, cows were fed individually, half of the daily concentrate allowance and returned to pasture. At 11:30 a.m., animals were retrieved from pasture and housed in a sheltered barn until the afternoon milking at 02:30 p.m. After the afternoon milking, cows were fed the second half of the concentrate and at 04:00 p.m. returned to pasture until the next day. Milk samples were taken three times per week to estimate milk composition.
Animals were dosed with a controlled-release capsule containing $8 \mathrm{~g}$ of $\mathrm{n}$-dotriacontane $\left(\mathrm{C}_{32}\right)$ and 8 $\mathrm{g}$ of n-hexatriacontane $\left(\mathrm{C}_{36}\right)$ to estimate forage DM intake. The release rate of the marker $\mathrm{C}_{36}$ was $312 \mathrm{mg}$ day $^{-1}$ as reported by Oliveira (2003). Chromium oxide (70.96\%) was dosed twice a day and started two days after the n-alkanes capsules were dosed. Chromium oxide was administered in the morning and in the afternoon, always after milking, in $5 \mathrm{~g}$ of shredded paper during $12 \mathrm{~d}$. After dosing, animals were observed for a short period of time to ensure that there was no regurgitation. Additionally, two crossbred steers weighing $300 \mathrm{~kg}$, using harness and bags for total fecal collection, were similarly dosed with the two markers to measure fecal recovery during three days. The bags were emptied twice a day.

Eight days after dosing the n-alkanes capsules, fecal samples were taken from rectum immediately after morning (06:30 a.m.) and afternoon (04:30 p.m.) milking during five consecutive days. Samples from different periods (morning and afternoon) and from different collection days for each animal were stored at $-20^{\circ} \mathrm{C}$. Fecal samples were dried at $60^{\circ} \mathrm{C}$ in a forced-draught oven up to constant weight. Dried samples were ground to pass a 1-mm mesh sieve and stored in plastic containers for subsequent chemical analysis.

Fecal samples were analyzed for chromium oxide according to Kimura \& Miller (1952) and the digestibility of the forage and concentrate samples was determined by an in vitro procedure (Tilley \& Terry, 1963 as modified by Goering \& Van Soest, 1970), discounting 11.9 percentage units to account for fecal metabolic matter (Van Soest, 1994). The n-alkane concentration in forage and fecal samples, tablets of the controlled-release capsules, and concentrate was determined in duplicate using the methodology described by Oliveira (2004).

To obtain the fecal output from forage (PFF) necessary to estimate forage intake, the fecal production associated with concentrate (PFC) was discounted from the total fecal output with the chromium oxide (TFP) using Equation 1.

Table 1 - Chemical composition and Cornell Net Carbohydrate and Protein System (CNCPS) estimated metabolizable energy for forage and concentrate

\begin{tabular}{lcccccccccc}
\hline Sample & $\mathrm{n}$ & $\mathrm{CP}$ & EE & NDF & NDF-N & ADF & ADF-N & LIGN & ASH & ME \\
\hline Forage & $12^{*}$ & 13.3 & 1.7 & 61.4 & 5.4 & 28.0 & 1.6 & 3.2 & 9.1 & 2.11 \\
Concentrate & 1 & 25.5 & 5.6 & $11^{*}$ & $6.6^{*}$ & $3.9 *$ & $2.5^{*}$ & $3.3^{*}$ & 16.1 & 2.86 \\
\hline
\end{tabular}

*Estimated using individual ingredient composition and their percentage of inclusion in the concentrate. Where: $\mathrm{n}=\mathrm{number}$ of samples; $\mathrm{CP}=$ crude protein; $\mathrm{EE}=$ ether extract; $\mathrm{NDF}=$ neutral detergent fiber; $\mathrm{NDF}-\mathrm{N}=\mathrm{N}$ bound to the $\mathrm{NDF}$ as a fraction of total $\mathrm{N} ; \mathrm{ADF}=$ acid detergent fiber; ADF-N = N bound to the ADF as a fraction of total $\mathrm{N}$; LIGN = lignin; ASH = ash; ME = metabolizable energy (Mcal kg-1 DM); (DM basis, \%). "Sample of three paddocks. 
$\mathrm{PFF}=\mathrm{TFP}-[\mathrm{CMSc}-(\mathrm{CMSc} \times \mathrm{DIVC})]$

where CMSc is the concentrate DM intake and DIVC is the in vitro digestibility of the concentrate.

The forage DM intake measured with chromium oxide was estimated according to Le Du \& Penning (1982) and with n-alkanes as proposed by Mayes et al. (1986).

The experimental design was completely randomized and the statistical analyses were performed using the SAS software (SAS Institute Inc., 2000). The fecal $\mathrm{C}_{35}, \mathrm{C}_{36}$ and $\mathrm{C}_{35}: \mathrm{C}_{36}$ n-alkane ratios and the chromium oxide variations between the morning and afternoon periods during the five days of collection, as well as their interactions were analyzed using the PROC MIXED procedure. A contrast analysis between days of collection was conducted with the HELMERT option, in which the mean of the current period (morning or afternoon) of every day was compared to the subsequent ones. The relationship between estimated metabolizable energy intake (MEI) and metabolizable energy (ME) requirement was analyzed through linear regression by the PROC REG procedure and a studentized residue analysis was used for identifying outliers. For studentized residues outside the -2 to 2 range, the observation was considered an outlier and excluded from the analysis. The command TEST of PROC REG was used to verify if the slope was different from unity. The difference in the estimated forage MEI between the two methods was detected using a pair wise comparison with the $t$-test analysis. The dry matter intake (DMI) was analyzed with the PROC GLM procedure using the command LSMEANS at $5 \%$ of probability.

\section{RESULTS AND DISCUSSION}

The mean values of pre- and post-grazing herbage mass were $1800(\mathrm{CV}=1 \%)$ and $1310(\mathrm{CV}=22 \%)$ $\mathrm{kg}$ of DM ha ${ }^{-1}$, respectively. The odd-chain n-alkanes profile between $\mathrm{C}_{23}$ and $\mathrm{C}_{35}$ was quantified for the whole sample, for the leaf and stem components of the hand-plucked forage and concentrate (Table 2).
Concentrations were higher for odd- than even-chained alkanes (data not shown). The n-alkanes $\mathrm{C}_{33}, \mathrm{C}_{31}$, and $\mathrm{C}_{29}$ presented the highest concentrations, in this order, except that $\mathrm{C}_{31}$ for the leaf component was slightly lower than $\mathrm{C}_{29}$, in agreement with results for other tropical forages (Oliveira et al., 1997; Genro et al., 2001). Forage intake estimated using the chromium oxide and the $\mathrm{C}_{35}: \mathrm{C}_{36}$ n-alkane ratio, the measured daily individual consumption of concentrate, and the mean intake of estimated metabolizable energy (Mcal day ${ }^{-1}$ ) are shown in Table 3.

Because the two treatments (CLA and control) had the same intake of concentrate and there was no difference in body weight and body condition score (Oliveira, 2003), the intake of metabolizable energy was assumed to be the total of the maintenance and lactation requirements in a steady-state condition. Thus, the regression between the ME requirement and the intake of ME from concentrate and the estimated forage intake was used to evaluate if markers were suitable to estimate forage intake. If the intercept equals zero and the slope equals one, estimates of energy intake are considered to properly balance the ME requirement. The linear regression $\left(R^{2}=0.27\right)$ using forage intake estimates based on the chromium oxide technique is shown in equation (2):

MEIntake $_{\mathrm{Cr}}=19.1+0.62 \mathrm{MEr}(\mathrm{RMSE}=2.71)$

where the intercept was different from zero $(P=0.02)$ and the slope different from zero $(P=0.03)$ but similar to one $(P=0.17)$.

Because the intercept was different from zero, the equality of the slope to one cannot be considered as an accurate measurement. The paired comparisons using $t$-test indicated that the difference between ME intake and $\mathrm{ME}$ requirement was not equal to zero $(P=0.0001)$, suggesting that chromium oxide was not a reliable marker to estimate fecal output in this study.

The linear regression $\left(\mathrm{R}^{2}=0.52\right)$ between the $\mathrm{ME}$ consumption and $\mathrm{ME}$ requirements using the forage intake estimated with the $\mathrm{C}_{35}: \mathrm{C}_{36} \mathrm{n}$-alkane ratio is shown in equation (3):

Table 2 - Odd-chain n-alkane concentration of whole, leaf blade, and sheath and stem of hand-plucked forage and concentrate.

\begin{tabular}{lccccccc}
\hline Sample* & $\mathrm{C}_{23}$ & $\mathrm{C}_{25}$ & $\mathrm{C}_{27}$ & $\mathrm{C}_{29}$ & $\mathrm{C}_{31}$ & $\mathrm{C}_{33}$ & $\mathrm{C}_{35}$ \\
\hline Forage & 35 & 55 & 68 & 71 & 106 & 137 \\
Leaf & 55 & 88 & 99 & 128 & 127 & 168 & 27 \\
Stem & 7 & 12 & 17 & 31 & 88 & 163 & 36 \\
Concentrate & 50 & 79 & 54 & 26 & 10 & 6 \\
\hline
\end{tabular}

* Samples were analyzed in duplicate. 
Table 3 - Estimated metabolizable energy requirements, measured intake of concentrate $(\mathrm{Ci})$, and estimated dry matter intake and metabolizable energy intake of forage ${ }^{1}$

\begin{tabular}{|c|c|c|c|c|c|c|}
\hline Treatment & $\mathrm{MEr}$ & $\mathrm{Ci}$ & $\mathrm{FCr}$ & $\mathrm{FC}_{35}: \mathrm{C}_{36}$ & $\mathrm{MECr}$ & $\mathrm{ME} \mathrm{C}_{35}: \mathrm{C}_{36}$ \\
\hline & Mcal d ${ }^{-1}$ & $\cdots$ & $\mathrm{kg} \mathrm{d}^{-1}$ & 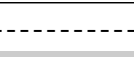 & (n) & $1^{-1} \ldots \ldots$ \\
\hline \multicolumn{7}{|l|}{ CLA } \\
\hline Mean $^{2}$ & 30.1 & 3.6 & 12.7 & 10.2 & 37.1 & 32.5 \\
\hline $\mathrm{CV}(\%)$ & 9.6 & 3.5 & 14.1 & 14.5 & 9.2 & 8.8 \\
\hline \multicolumn{7}{|l|}{ Megalac } \\
\hline Mean $^{2}$ & 29.1 & 3.5 & 14.3 & 10.0 & 38.6 & 31.4 \\
\hline CV (\%) & 8.5 & 7.9 & 14.6 & 14.1 & 6.6 & 9.2 \\
\hline
\end{tabular}

${ }^{1}$ Values estimated for intake of DM $\left(\mathrm{kg} \mathrm{d}^{-1}\right)$ and $\mathrm{ME}\left(\mathrm{Mcal} \mathrm{d}^{-1}\right)$ using chromium oxide (FCr and MECr, respectively) and $\mathrm{n}$-alkanes $\left(\mathrm{FC}_{35}: \mathrm{C}_{36}\right.$ and $\mathrm{ME} \mathrm{C}_{35}: \mathrm{C}_{36}$, respectively). ${ }^{2}$ Mean of ten animals per treatment.

MEIntake $_{\mathrm{C} 35: \mathrm{C} 36}=9.3+0.77 \mathrm{MEr}(\mathrm{RMSE}=2.04) \quad$ [3]

in which the intercept is not different from zero $(P=0.09)$ and the slope different from zero $(P=0.0005)$ but similar to one $(P=0.21)$

These findings indicate that the changes in energy requirement resulted in changes of intake of metabolizable energy, suggesting that the $\mathrm{C}_{35}: \mathrm{C}_{36}$ n-alkane ratio was a more reliable marker than $\mathrm{Cr}_{2} \mathrm{O}_{3}$ to estimate forage intake, even though $48 \%$ of the variation in energy intake was not accounted for by variations in energy requirements.

Although the fecal recoveries for chromium oxide $(89.1 \%)$ and $\mathrm{C}_{36}(96 \%)$ n-alkane have been measured and used in the calculations of forage intake estimates, variation in excretion for the different markers was investigated among periods and days of collection. In Table 4, the fecal concentrations are presented for the morning and afternoon periods during five consecutive days of fecal collection.

There was no interaction between day of collection and period of the day for both markers. There was a treatment effect on fecal concentration of chromium oxide in the afternoon period on the fifth day of collection $(\mathrm{CLA}=976 \mathrm{vs}$. $\mathrm{MEG}=712 \mathrm{mg}$, $P=0.004)$. Unlike the findings of this experiment, Ohajuruka \& Palmquist (1991), measuring intake in lactating dairy cows with external markers, found no effect of added fat on the concentration and fecal recovery of chromium oxide or concentration of $\mathrm{C}_{31}$ and $\mathrm{C}_{32}$ n-alkanes. Pereira et al. (1983) used chromium oxide in cattle receiving different levels of soybean oil plus formaldehyde in the diet. The authors found an effect of soybean oil addition on DM digestibility using chromium, but not on fecal recovery of the marker. In this study chromium oxide concentrations varied among days $(P=0.02$, Figure 1$)$ within and between periods (morning $\mathrm{mg} \mathrm{Cr}=1132.7+106.5 \times$ day $26.7 \times$ day $^{2}$, afternoon $\mathrm{mg} \mathrm{Cr}=929.9+106.5 \times$ day $-26.7 \times$ day $^{2}, P=0.0001$ ). These are similar find-

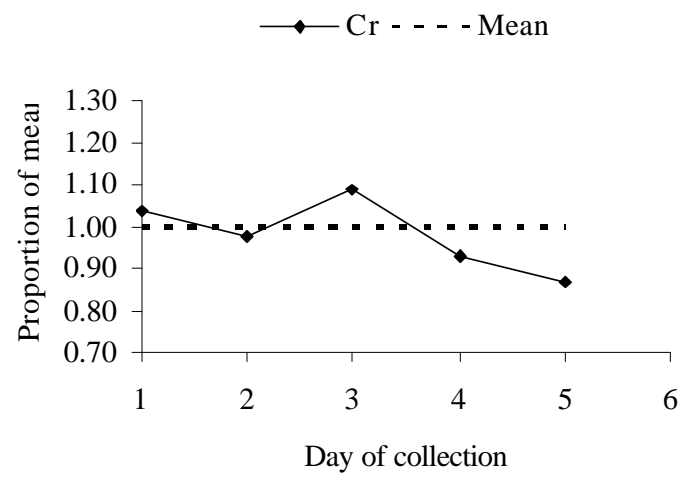

Figure 1 - Mean variation in the chromium concentrations in feces expressed as proportions of the mean concentration for each cow over five days.

ings in relation to those of Lima et al. (1980), who studied fecal excretion of chromium in grazing cattle and reported largest concentration values during the morning period $($ morning $=1158$ vs. afternoon $=955$ mg, $P=0.01)$. Kameoka et al. (1956) mentioned the possibility of chromium oxide accumulating in some parts of the digestive tract, with later excretion of larger amounts in subsequent times of the day, and that the variation of the amount of daily excreted feces, could also contribute to alter fecal concentration of the marker regardless of animals being kept indoors or grazing.

Similar to the findings regarding chromium oxide, there were effects of treatment (CLA $=62$ vs. $\mathrm{MEG}=55 \mathrm{mg}, P=0.01$ ), period (morning $=54 \mathrm{vs}$. afternoon= $63 \mathrm{mg}, P=0.01$ ); day of collection (linear; CLA Morning, $\mathrm{mg} \mathrm{C}_{35}=48.05+3.4 \times$ day; CLA afternoon, $\mathrm{mg} \mathrm{C}_{35}=36.2+3.4 \times$ day; MEG morning, $\mathrm{mg} \mathrm{C}_{35}=40.7+3.4 \times$ day; MEG afternoon, $\mathrm{mg} \mathrm{C}_{35}=$ $48.9+3.4 \times$ day; $P=0.0001)$ on the fecal concentrations of the natural $\mathrm{C}_{35} \mathrm{n}$-alkane of the diet.

Excretion of the $\mathrm{C}_{36} \mathrm{n}$-alkane was affected by treatment on the morning of the fourth day of collection $(P=0.01)$, and there was a quadratic effect 
Table 4 - Fecal concentrations of chromium, $\mathrm{C}_{35}, \mathrm{C}_{36}$ and $\mathrm{C}_{35}: \mathrm{C}_{36} \mathrm{n}$-alkane ratio for each period (morning and afternoon) in five consecutive days.

\begin{tabular}{|c|c|c|c|c|c|c|c|c|c|c|}
\hline Mk/Tt. & M1 & M2 & M3 & M4 & M5 & A1 & $\mathrm{A} 2$ & A3 & A4 & A5 \\
\hline & - & & 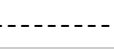 & -1 & $--\mathrm{mg}$ & DM --. & $-\cdots-\cdots$ & $-\cdots$ & $\cdots$ & $\cdots \cdots$ \\
\hline \multicolumn{11}{|l|}{ Chr } \\
\hline CLA & 1222 & $1268 *$ & $1367 *$ & 1091 & 995 & 1052 & $1102 *$ & $1069 *$ & 935 & $976 a$ \\
\hline MEG & 1142 & $1252 *$ & $1183^{*}$ & 1070 & 983 & 976 & 963 & 943 & 829 & $712 b$ \\
\hline \multicolumn{11}{|l|}{$\mathrm{C}_{35}$} \\
\hline CLA & $55^{*}$ & $81^{*}$ & 63 & $68 *$ & $70 a$ & $64 *$ & $100 *$ & $74 *$ & $85^{*}$ & $77 \mathrm{a}$ \\
\hline MEG & $55^{*}$ & $86^{*}$ & 64 & $70^{*}$ & $57 \mathrm{~b}$ & $58 *$ & $102 *$ & $68^{*}$ & $79 *$ & $63 b$ \\
\hline \multicolumn{11}{|l|}{$\mathrm{C}_{36}$} \\
\hline CLA & 76 & $106^{*}$ & 69 & $71 * b$ & 66 & $72 *$ & $109 *$ & 75 & $83 *$ & 67 \\
\hline MEG & 71 & $107 *$ & 74 & $80 * a$ & 62 & $67 *$ & $114^{*}$ & 70 & $68 *$ & 60 \\
\hline \multicolumn{11}{|l|}{$\mathrm{C}_{35}: \mathrm{C}_{36}$} \\
\hline CLA & $0.76^{*}$ & $0.80 *$ & 0.95 & 0.96 & 1.10 & $0.90 *$ & $0.96^{*}$ & $1.01 *$ & 1.12 & 1.19 \\
\hline MEG & $0.82 *$ & $0.84 *$ & 0.90 & 0.89 & 0.95 & $0.93 *$ & $0.94 *$ & $1.00 *$ & 1.15 & 1.01 \\
\hline
\end{tabular}

$(P=0.01)$ of day of collection $\left(\mathrm{mg} \mathrm{C}_{36}=40.02+20.5\right.$ $\times$ day $-3.02 \times$ day $\left.^{2}\right)$. Fecal concentration ratio for the $\mathrm{C}_{35}: \mathrm{C}_{36}$ alkane pair did not vary with treatments $(P=$ $0.49)$, but there was a period of the day (morning= 0.89 vs. afternoon $=1.02 \mathrm{mg}, P=0.01)$ and a linear effect of collection day (afternoon $\mathrm{mg} \mathrm{C}_{35}: \mathrm{C}_{36}=0.85$ $+0.058 \times$ Day; morning $\operatorname{mg~C}_{35}: \mathrm{C}_{36}=0.72+0.058 \times$ day, $P=0.01$ ). Figures 2 and 3 show the variation of concentration of individual $\mathrm{C}_{35}$ and $\mathrm{C}_{36} \mathrm{n}$-alkanes and the $\mathrm{C}_{35}: \mathrm{C}_{36}$ ratio in the feces throughout the day as proportions of the mean value, respectively.

It is possible that the difference between treatments is due to differences in saturation, which might have influenced the fiber digestion, altering the passage rate, and consequently modified the fecal concentrations of the markers. Mayes et al. (1986) found smaller fecal concentrations for the natural $\mathrm{C}_{27}$ and $\mathrm{C}_{29}$ $\mathrm{n}$-alkanes coming from the diet when animals received synthetic $\mathrm{C}_{28}$ and $\mathrm{C}_{32} \mathrm{n}$-alkanes in pellets with a stearic and palmitic acids mix.

The period of the day effect on the fecal concentrations of $\mathrm{C}_{35}, \mathrm{C}_{35}: \mathrm{C}_{36}$ ratio, and chromium oxide concentration might have been caused by experimental handling. Grazing was more intense in the afternoon and at night, resulting in a larger ruminal pool at this time, which could have caused larger excretions and smaller fecal concentrations in the afternoon of the following day. So, differences in the rates of flow of both liquid and solid phases of digesta throughout the day could have resulted in the diurnal variation in fecal concentration of the markers. Dillon (1989)

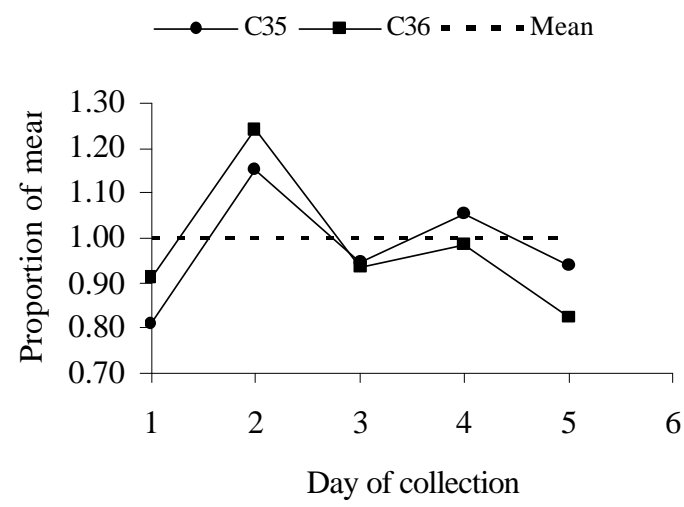

Figure 2 - Mean variation in the feces concentrations of $\mathrm{C}_{35}$ and $\mathrm{C}_{36}$ n-alkane concentration expressed as proportions of the mean concentration for each cow over five days.

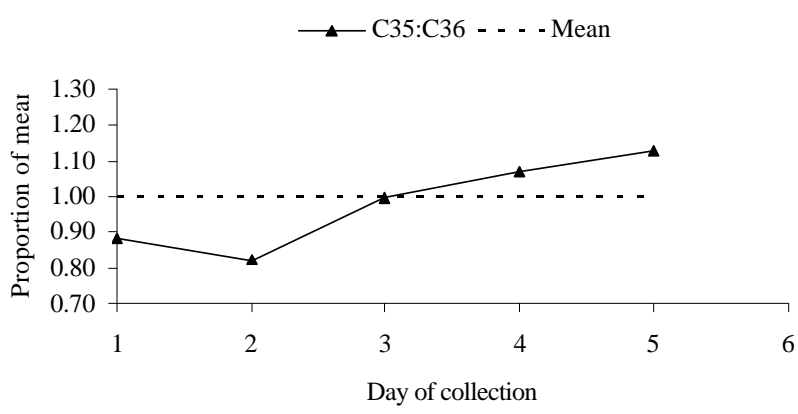

Figure 3 - Mean variation of the ratio in the feces of $\mathrm{C}_{35}$ oddchain (diet) concentration to $\mathrm{C}_{36}$ even-chain (dosed) n-alkane concentration expressed as proportions of the mean concentration for each cow over five days. 
worked with lactating cows and found day-to-day variation in fecal concentration of chromium oxide and diurnal and daily systematic variations in fecal concentration of the $\mathrm{C}_{35}: \mathrm{C}_{36}$ ratio. The author concluded that feeding management may have contributed to these variations. The increasing linear effect on $\mathrm{C}_{35}$ fecal concentration during the days of collection might represent an increase in consumption of stem fraction of the herbage in relation to leaf since the leaf:stem ratio decreased during the duration of grazing. Moreover, $\mathrm{n}$-alkanes appear in larger concentrations in the stem fraction. The linear increase in consumption of the $\mathrm{C}_{35}$ and the quadratic excretion of the $\mathrm{C}_{36}$ n-alkanes resulted in the linear increase in fecal concentration of the $\mathrm{C}_{35}: \mathrm{C}_{36}$ ratio.

Individual variations of the n-alkanes did not interfere with forage intake estimation, but the variation in the fecal concentration ratio of the pair of nalkanes used in the estimation process is very important (Dove \& Mayes, 1991; Mayes \& Dove, 2000).

Malossini et al. (1996) worked with lactating cows and compared the estimates of forage intake obtained with chromium oxide and with the $\mathrm{C}_{31}: \mathrm{C}_{32}$ n-alkane ratio. The authors reported that the methods differed from each other, but there was a positive correlation between them $(r=0.62)$.

Further investigation is needed for the comparison of these two techniques used to measure forage intake, with special attention on (a) the incomplete fecal recovery of markers, (b) the rectal sampling procedure commonly used to obtain fecal samples may not provide representative estimates of fecal concentration of the markers given the variability related to day and time of the day the collection was carried out, and (c) the forage digestibility values might have been influenced in many ways and may not be accurate.

\section{CONCLUSIONS}

The estimates of forage intake obtained with the pair of n-alkanes, the natural $\mathrm{C}_{35}$ of the diet and synthetic $\mathrm{C}_{36}$ orally supplied by controlled-release capsules, and those obtained with the chromium oxide and in vitro digestibility procedure differed. The estimate of forage intake obtained with $\mathrm{C}_{35}: \mathrm{C}_{36}$ n-alkane ratio was more precise than those obtained with chromium oxide and in vitro digestibility. The fecal concentrations of the indicators varied among periods of the day and days of sampling during fecal collection, indicating that handling of animals during the experiment may have influenced fecal concentration of n-alkanes and that rectal collection twice a day failed to provide reliable estimates of daily concentration of both markers in the feces.

\section{ACKNOWLEDGMENTS}

To Fundação de Amparo à Pesquisa do Estado de São Paulo (FAPESP) for financial support and to Church \& Dwight for the donation of CLA-60 and Megalac.

\section{REFERENCES}

ASSOCIATION OF OFFICIAL ANALYTICAL CHEMISTS AOAC. Official methods of analysis. 16.ed. Gaithersburg: AOAC, 1997.

DILLON, P.G. The use of dosed and herbage n-alkanes to estimate herbage intake with dairy cows. Cork: National University of Ireland, 1989. 152p. (MSc. - Thesis).

DOVE, H. Using the $n$-alkanes of plant cuticular wax to estimate the species composition of herbage mixtures. Australian Journal of Agricultural Research, v.43, p.1711-1724, 1992.

DOVE, H.; MAYES, R.W. The use of plant wax alkanes as marker substances in studies of the nutrition of herbivores: a review. Australian Journal of Agricultural Research, v.42, p.913952, 1991.

DOVE, H.; MOORE, A.D. Using a least-squares optimization procedure to estimate botanical composition based on the alkanes of plant cuticular wax. Australian Journal of Agricultural Research, v.46, p.1535-1544, 1995.

FOX, D.G.; TEDESCHI, L.O.; TYLUTKI, T.P.; RUSSELL, J.B.; Van AMBURGH, M.E.; CHASE, L.E.; PELL, A.N.; OVERTON, T.R. The Cornell Net carbohydrate and protein system model for evaluating herd nutrition and nutrient excretion. Animal Feed Science and Technology, v.112, p.29-78, 2004.

GENRO, T.C.M.; PRATES, E.R.; HERRERO, M.; THIAGO, L.R.L.S.; XAVIER, G.F. Estimativas de consumo de bovinos em pastejo utilizando n-alcanos como indicadores em gramíneas tropicais (compact disc). In: REUNIÃO ANUAL DA SOCIEDADE BRASILEIRA DE ZOOTECNIA, 37., Viçosa, 2000. Anais. Viçosa: SBZ, 2000.

GENRO, T.C.M.; PRATES, E.R.; THIAGO, L.R.L.S.; HERRERO, M.; SABATEL, V. Identification and quantification of n-alkanes in three tropical grasses. In: INTERNATIONAL GRASSLAND CONGReSS, 19., Águas de São Pedro, 2001. Proceedings. Piracicaba: FEALQ, 2001. p.402-403.

GOERING, H.K.; Van SOEST, P.J. Forage fiber analyses apparatus, reagents, procedures and some applications. Washington: USDA, 1970. (Agriculture Handbook, 379).

KAMEOKA, K.; TAKAHASHI, S.; MORIMOTO, H. Variation in the excretion of chromic oxide by ruminants. Journal of Dairy Science, v.39, p.462-467, 1956.

KIMURA, F.T.; MILLER, V.L. Chromic oxide measurement: improved determination of chromic oxide in cow feed and feces. Journal of Agricultural and Food Chemistry, v.11, p.633$635,1952$.

LE DU, Y.L.P.; PENNING, P.D. Animal based techniques for estimating herbage intake. In: LEAVER, J.D. Herbage intake handbook. Hurley: British Grassland Society, 1982. p.37-75.

LIMA, M.A.; VIANA, J.A.C.; RODRIGUES, N.M., ESCUDER, C.J. $\mathrm{O}$ uso do óxido crômico para estimar a excreção fecal de novilhos zebus em pastejo. Revista Brasileira de Zootecnia, v.9, p.188202, 1980 .

MALOSSINI, F.; BOVOLENTA, S.; PIASENTIER, E.; PIRAS, C.; MARTILLOTTI, F. Comparison of n-alkanes and chromium oxide methods for estimating herbage intake by grazing dairy cows. Animal Feed Science and Technology, v.61, p.155165, 1996.

MAYES, R.W.; DOVE, H. Measurement of dietary nutrient intake in free-ranging mammalian herbivores. Nutrition Research Review, v.13, p.107-138, 2000. 
MAYES, R.W.; LAMB, C.S. The possible use of n-alkanes in herbage as indigestible faecal markers. Proceedings of the Nutrition Society, v.43, p.39, 1984.

MAYES, R.W.; LAMB, C.S.; COLGROVE, P.M. The use of dosed and herbage n-alkanes as markers for determination of herbage intake. Journal of Agricultural Science, v.107, p.161-170, 1986.

OHAJURUKA, O.A.; PALMQUIST, D.L. Evaluation of n-alkanes as digesta markers in dairy cows. Journal of Animal Science, v.69, p.1726-1732, 1991.

OLIVEIRA, D.E. Uso da técnica de n-alcanos para medir o aporte de nutrientes através de estimativas do consumo de forragem em bovinos. Piracicaba: USP/ESALQ, 2003. 129p. (Tese Doutorado).

OLIVEIRA, D.E. Determinação de alcanos. Manual de extração e análise cromatográfica em forragens, concentrados e fezes. Piracicaba: FEALQ, 2004. 30p.

OLIVEIRA, D.E.; PRATES, E.R.; PERALBA, M.C.R. Identificação e quantificação de n-alcanos presentes nas ceras de plantas forrageiras. Revista Brasileira de Zootecnia, v.26, p.881$886,1997$.

OLIVEIRA, D.E.; PRATES, E.R.; PERALBA, M.C.R. Digestibilidade determinada pelo método indireto usando o nalcano C35. Revista Brasileira de Zootecnia, v.29, p.848$852,2000$.

OLIVEIRA, D.E.; MEDEIROS, S.R.; AROEIRA, L.J.M.; PERALBA, M.C.R.; LANNA, D.P.D. The use of n-alkanes to estimate forage intake and diet composition of crossbred dairy cows treated with conjugated linoleic acid (CLA) and grazing a tropical pasture. In: WORLD CONFERENCE ON ANIMAL PRODUCTION, 9., Porto Alegre, 2003. Proceedings. Porto Alegre, 2003. p.39.
PEREIRA, J.C.; GARCIA, J.A.; SILVA, J.F.C.; LEÃO, M.I. Estudo da digestão em bovinos fistulados, alimentados com rações tratadas com formaldeído e contendo óleo. I. Influência dos períodos de coletas nas estimativas do fluxo e da excreção de matéria seca. Revista Brasileira de Zootecnia, v.12, p.399428, 1983.

PRATES, E.R. Nutritional evaluation of pensacola bahiagrass pasture by animal and laboratory techniques. Gainesville: University of Florida, 1974. 158p. (Thesis - PhD).

SAS INSTITUTE. SAS/STAT. Guide for personal computers. Cary, 2000. 1v.

SCHNEIDER, B.H.; FLATT, W.P. The evaluation of feeds through digestibility experiments. Athens: University of Georgia Press, 1975. 423p.

TEDESCHI, L.O.; FOX, D.G.; PELL, A.N.; LANNA, D.P.D.; BOIN, C. Development and evaluation of a tropical feed library for the Cornell Net Carbohydrate and Protein System model. Scientia Agricola, v.59, p.1-18, 2002.

TILLEY, J.M.A.; TERRY, R.A. A two-stage technique for the in vitro digestion of forage crops. Journal of British Grassland Society, v.18, p.104-111, 1963.

Van SOEST, P.J. Nutritional ecology of the ruminant. 2.ed. Ithaca: Cornell University Press, 1994. 476p.

Van SOEST, P.J.; ROBERTSON, J.B.; LEWIS, B.A. Methods for dietary fiber, neutral detergent fiber, and nonstarch polysaccharides in relation to animal nutrition. Journal of Dairy Science, v.74, p.3583-3597, 1991.

Received December 19, 2005

Accepted February 09, 2007 